\title{
BCECBITHЯ ICTOPIЯ
}

УДК 72.725 .9

DOI https://doi.org/10.32838/2663-5984/2020/1.8

Андрейчик Е.В.

Полоцкий государственный университет

\section{ОХРАНА НЕДВИЖИМЫХ ИСТОРИКО-КУЛЬТУРНЫХ ЦЕННОСТЕЙ В РЕГИОНАХ БЕЛАРУСИ В 1990-Е - НАЧАЛЕ 2000-Х ГГ. (НА ПРИМЕРЕ ГРОДНЕНСКОЙ ОБЛАСТИ)}

У статті розглядається діяльність місиевих виконавчих органів влади базового та обласного рівня Республіки Білорусь з охорони нерухомих історико-культурних иінностей. На основі раніше неопублікованих архівних джерел Державного архіву Гродненської області розглядається діяльність структурних підрозділів Гродненського обласного виконавчого комітету в період 1991-2005 рр. у сфері охорони, збереження, відновлення і пристосування під нові соиіокультурні функиії матеріальних нерухомих історико-культурних цінностей багатих на історико-культурні иінності Гродненського регіону та міста Гродно в складний соціальноекономічний і суспільно-політичний період кіния XX $\mathrm{cm}$.

Особливу увагу автор приділяє діяльності Головного управління архітектури та містобудування Гродненського обласного виконавчого комітету, діяльності Управління з реставрачіі та консервації пам'яток історії та культури, Державного виробничо-комериійного управління з реставраиї̈ пам'яток історії та культури. Аналізується перша обласна комплексна програма дослідження, збереження та пропаганди культурної спадщини.

У дослідженні розглядаються особливості тогочасного механізму управління регіональним фондом нерухомих історико-культурних иінностей, які включають реалізацію в тому числі иільових обласних і міських програм з охорони, збереження, відновлення та реставрації пам'яток історії та архітектури в межах Гродненської області та міста Гродно, комплекс охоронних заходів із благоустрою територій охоронних зон населених пунктів області, реставрації та консерваџї нерухомих об'єктів історико-культурної спадщини (замків, палаиів, садиб, храмів), реконструкиії історичної забудови населених пунктів області та їх благоустрою, меморіалізації пам'ятних місиь, пов'язаних із подіями Першої та Другої світової війни.

Ключові слова: культурна спадщина, історико-культурні иінності, охорона пам'яток, органи місиевого управління та самоврядування, Білорусь, Гродненська область.

Постановка проблемы. Определение механизмов деятельности исполнительно-распорядительных органов власти регионального, базового и первичного территориального уровней является актуальным направлением в изучении административных процессов в сфере сохранения историко-культурного наследия. Законодательством Беларуси на органы местного управления возложена ответственная миссия реализации мероприятий по реализации государственной политики в сфере охраны историко-культурного наследия, содействию осуществлению мероприятий по сохранению и восстановлению историко-культурных ценностей, организации и осуществлению мероприятий по выявлению и проведению учета историко-культурных ценностей. Среди органов местного управления Беларуси деятельность Гродненского областного исполнительного комитета была в рассматриваемый период достаточно характерной, но при этом имела и весьма примечательные особенности в свете наличия в регионе большого (если не сказать самого большого в Беларуси) количества недвижимых объектов культурного наследия.

Анализ последних исследований и публикаций. Наиболее значительными в области теории и практики охраны и государственного управления недвижимым историко-культурным ценностями, сохранения памятников наследия города Гродно и Гродненщины являются монографиче- 
ские исследования и отдельные публикации таких авторов, как И.Э. Мартыненко [11], В.Г. Корнелюк [18], В.В. Швед [18], В.Ю. Саяпин [13; 14; 15], А.П. Гостев [18], В.А. Ганский [16; 17], А.А. Добриян [18], А.Н. Чернякевич [18] и других. Несмотря на наличие отдельных публикаций в этой области, важные вопросы остаются практически неизученными, особенно в контексте становления научного знания об управлении недвижимым наследием и его недавнего исторического опыта, что определяет высокую степень актуальности этого исследования в свете особой социальной значимости рассматриваемой проблемы.

Постановка задания. Целью статьи является анализ административных процессов и рассмотрение специфики организационно-управленческих механизмов реализации властных полномочий органами исполнительной власти в регионах Беларуси в 1990-е - начале 2000-х гг. по вопросу реализации государственной политики в области охраны недвижимого историко-культурного наследия.

Изложение основного материала исследования. В результате реформирования системы местного управления и самоуправления в начале 1990-х гг., а точнее с принятием Закона «О местном управлении и самоуправлении в Республике Беларусь» от 20.02.1991 г. и Постановления Президиума Верховного Совета Республики Беларусь № 512 от 06.10.1994 г. произошли изменения в наименовании органов власти базового территориального уровня. Гродненский исполнительный комитет получил права юридического лица, из его названия исчезло упоминание Совета народных депутатов. Следующим шагом на пути реформирования органов власти стал Указ Президента № 122 от 23.09.1994 г. об изменении структуры центральных органов управления Республики Беларусь.

С целью приведения норматива и укрупнения структурных подразделений было принято решение Гродненского облисполкома № 342 от 14.11.1994 г., согласно которому на базе Управления культуры было образовано Управление культуры и печати. Решением облисполкома № 99 от 28.03.1995 г. Управление культуры и печати было реорганизовано в Управление культуры и информации [9, с. 2-18]. Изменения в структуре государственного аппарата на региональном уровне привели к совершенствованию структуры подчиненных подразделений. Последнее изменение структуры Гродненского облисполкома произошло с Указом Президента № 89 от 27.02.1995 г.
Согласно нормативу, управляющий корпус Гродненского облисполкома состоял из председателя облисполкома, первого заместителя председателя, четырех заместителей председателя, управляющего делами. Подразделения по развитию социальной сферы включали управление культуры и информации, совет по делам религий; органы по строительству, архитектуре и жилищнокоммунальному хозяйству включали главное управление архитектуры, градостроительства и территориального планирования (отдел по делам строительства и архитектуры) [9, с. 2-18].

В результате оптимизации деятельности органов местного управления было принято решение облисполкома № 305 от 19.08.1996 г., согласно которому управление культуры и информации Гродненского облисполкома было переименовано в Управление культуры. Штатный корпус специалистов Управления состоял из инспекторов по охране историко-культурного наследия в лице музейных сотрудников. Следует подчеркнуть, что специалисты занимались именно материальными движимыми ценностями. Управлением культуры и информации каждый год разрабатывался комплексный перспективный план работы, оно проводило и протоколировало результаты совещаний заседаний [9, с. 23].

Штатный корпус специалистов, занимавшихся охраной историко-культурного наследия, претерпел изменения с течением времени. Так, еще в 1988 г. управление культуры имело службы старших инспекторов по музеям, которые были объединены в отдел учреждений культуры, народного творчества и искусства. В 1993 г. из отдела были образованы три службы ведущих специалистов по библиотекам, музеям и клубной работе, народному творчеству и паркам. С 1994 г. службы ведущих специалистов по библиотекам и музеям стали службами главных специалистов по библиотекам и музеям, охране памятников истории и культуры.

Функции сохранения материальных недвижимых историко-культурных ценностей в структуре Гродненского облисполкома в рассматриваемый период возлагались также и на Главное управление архитектуры и градостроительства, Управление культуры и информации. Еще в 1945 г. был образован отдел по делам строительства и архитектуры, который в 1963 г. был реорганизован в Управление архитектуры и строительства. С 1989 г. оно было переименовано в Главное управление архитектуры и строительства. В компетенцию управления входило осуществление архитектурно-строительного контроля за каче- 
ством восстановления, реставрации и охраны памятников архитектуры, разработка проектов планирования застройки населенных пунктов, проведение экспертизы проектов и смет [7, с. 3-6].

Постановлением Совета Министров от 17.01.1991 г. было образовано Управление по реставрации и консервации памятников истории и культуры Гродненской области. Деятельность управления осуществлялась согласно Положению о Главном управлении архитектуры и градостроительства от 1994 г. Среди основных задач, обозначенных в документе, на Главное управление архитектуры и градостроительства облисполкома возлагались обязанности реализации государственной политики в сфере архитектурной и градостроительной деятельности, постановка и решение текущих перспективных задач комплексного социально-экономического развития территории области, координация деятельности инвесторов по обеспечению комплексности при проектировании новой и реконструкции существующей сложившейся застройки населенных пунктов с учетом сохранения архитектурного облика исторической застройки и бережного использования памятников зодчества, творческого подхода в развитии архитектуры на основе учета историко-культурного наследия и традиций, содействие развитию прогрессивных форм и методов реконструкции и реставрации. В связи с возложенными задачами главное управление участвовало в разработке и согласовании правил застройки населенных пунктов, регулировало вопросы их реконструкции, реставрации, благоустройства, формирования облика. Положение о Главном управлении архитектуры и градостроительства Гродненского облисполкома, а точнее его п. 4.11, устанавливало порядок утверждения и выдачи инвесторам архитектурно-планировочных заданий на проектно-изыскательские работы под комплексную реставрацию, капитальный ремонт, благоустройство территорий.

Главное управление архитектуры и градостроительства должно было оказывать содействие государственным и общественным органам охраны памятников истории и культуры в выполнении им функций охраны, к числу которых относилась реставрация и хозяйственное использование объектов, установление вокруг них защитных границ, рассмотрение и согласование проектов регенерации, ремонта, реставрации памятников архитектуры. В функционал Главного управления архитектуры и градостроительства входило осуществление организационно-методического надзора над деятельностью управлений и отделов архитектуры и градостроительства районных и городских исполнительных комитетов, оказание помощи в комплектовании специалистами архитектурно-строительных органов [7, с. 9]

Особенностью организационно-управленческого механизма охраны материальных недвижимых историко-культурных ценностей Гродненской области стало образование экономически самостоятельных ремонтно-реставрационных и проектных подразделений по районам области в структуре управления по реставрации. К 1992 г. было сформировано 8 организаций, среди которых «Гроднореставрация», «Сморгоньреставрация», «Новогрудокреставрация», «Слонимреставрация», «Спецпроектреставрация» и другие.

Причинами изменения структуры управления стал недостаток капитальных вложений. Важными шагами на пути совершенствования экономической и хозяйственной самостоятельности стали мероприятия по проведению единой политики в сфере ремонта и реставрации. Существовавшая организационная форма управления по реставрации и консервации материальных недвижимых историко-культурных ценностей не позволяла осуществлять хозрасчетные отношения, способствовавшие формированию Фонда реставрации.

Планировалось, что инновационным подходом станет принятие в установленном законодательством порядке на баланс экономически самостоятельными ремонтно-реставрационными и проектными подразделениями по регионам области недвижимых памятников архитектуры, кварталов и районов исторической застройки населенных пунктов, проведение реставрационных работ с последующей сдачей в аренду. Организационно-управленческие направления деятельности должны были быть сосредоточены на таких мероприятиях: сбор и концентрация долевых средств арендаторов на нужды финансирования научноисследовательских и реставрационных работ, координация процессов создания совместных предприятий, а также стимулирование привлечения их средств на ремонтно-реставрационные работы с последующим предоставлением площадей на правах аренды и направление полученной части доходов в Фонд реставрации, закупка материалов, выполнение столярных, металлических изделий и их реализация с отчислением основной части прибыли в Фонд реставрации.

В 1992 г. Гродненский облисполком преобразовал Управление по реставрации и консервации в Государственное производственно-коммерче- 
ское управление по реставрации памятников истории и культуры с целью поиска, накопления и концентрации финансовых ресурсов, направленных на увеличение реализации объемов научно-исследовательских, проектных, ремонтных, реставрационных работ по памятникам архитектуры, исторической застройке населенных пунктов. Устав и структура были утверждены решением Гродненского облисполкома от 29.05.1992 гг. № 139.

В соответствии с дополнительными функциями управления, исполком Гродненского городского совета передал управлению права владения, использования и сдачи в аренду зданий, кварталов исторической застройки города Гродно. Главным управлением по реставрации и консервации была передана Управлению по реставрации памятников истории и культуры Гродненского облисполкома производственная база с комплексом цехов по обработке дерева и металла. Уже в 1992 г. сформирована структура проектно-реставрационного треста, которым было освоено 29 млн бел. руб. Был сформирован Фонд реставрации, который формировался из республиканских и областных источников финансирования и инвестиций, принятых от коммерческих структур для реставрации исторической застройки с последующей передачей в аренду. В 1993 г. было освоено 231 млн бел. руб, из республиканского бюджета - 300 млн бел. руб., от посторонних организаций - 30 млн бел. руб.

Управлением по реставрации и консервации в 1992 г. был сформирован областной титульный список объектов, на который были переосвоены средства в размере 149 млн бел. руб., на объекты республиканского титульного списка было освоено 70 млн бел. руб. Всего за 1993 г. было освоено 710,8 млн бел. руб. За период действия реставрационных организаций Гродненской области в системе Министерства культуры с 1970 по 1991 гг. было введено в эксплуатацию незначительное количество объектов: усадьба $\Phi$. Богушевича в деревне Кушляны Сморгонского района, комплекс базилианского монастыря в городе Гродно, дом-музей Э. Ожешко в этом же городе. Показательно, что с момента образования областного управления по реставрации памятников в системе Главного управления при Совете Министров Республики Беларусь были введены в эксплуатацию памятники архитектуры XVIII в.: костел св. Андрея в городе Слоним, памятник архитектуры XIX в. - костел в деревне Деречин Зельвенского р-на, памятник архитектуры XIX в. здание по ул. Замковой 16 (дворец Хрептовичей) с приспособлением под музей. Введена в эксплуа- тацию усадьба Огинского в деревне Залесье Сморгонского района - памятник архитектуры XVI в.

Таким образом, структура в составе областного управления, в которую входили проектная и 6 строительных организаций, в сложных экономических условиях проявила себя как весьма жизнеспособная. На протяжении нескольких лет неоднократно проводились мероприятия по структурной реорганизации с целью оптимизации деятельности подразделения: 01.05.1992 г. Управление по реставрации и консервации памятников истории и культуры Гродненского облисполкома претерпело трансформацию в Государственное производственно-коммерческое управление по реставрации памятников истории и культуры (с 22.05.1995 г. структура была переименована в Дирекцию по реставрации историко-культурных ценностей при Гродненском облисполкоме и функционировало до 04.07.2001 г. После этого было переименовано в Областное производственное унитарное предприятие «Гродно-Реставрация» Гродненского облисполкома (до 30.12.2004 г.).

Ориентиры в процессе восстановления материальных недвижимых историко-культурных ценностей были разработаны в 1991 г. Областной комплексной программой исследования, сохранения и пропаганды культурного наследия «Наследие». Основными направлениями документа было определено выявление и учет историкокультурных ценностей; реставрация, консервация архитектурных памятников; мемориализация памятных мест, связанных с именами знаменитых земляков, участников и жертв войн; содействие развитию историко-краеведческой работы, эстетизация городского пространства.

В рамках реализации государственной политики были запланирован и выполнен ряд мероприятий по восстановлению архитектурного наследия областного центра. В этом направлении Гродненским облисполкомом было принято решение «О формировании художественного облика города» от 28.10.1991 г. № 263. Документ содержал концептуальные основы «... создания художественно осмысленной, экономически целесообразной и пригодной для жизни городской среды». Среди основных направлений концепции выделялось формирование художественной среды города, разработка модульных элементов малых форм, эстетизация рекламы, уличной торговли, благоустройство общественных территорий [10, с. 47-51].

На Управление по реставрации и консервации памятников истории и культуры, которое возглавлял А.В. Хомко, возлагалось проведение рестав- 
рации взятых под охрану зданий исторического центра города. Мероприятия были проведены в рамках реализации генерального плана города. Заседанием исполнительного комитета сессии областного совета было принято решение «О развитии и охране историко-культурного наследия». Согласно документу Управление культуры Гродненского облисполкома обязывалось разработать направления по поддержке национальной культуры, предусмотреть использование архитектурных памятников под новые социокультурные нужды $[9$, с. 10].

Наряду с Областной комплексной программой исследования, сохранения и пропаганды культурного наследия «Наследие» отдельно готовилась городская программа «Наследие». Городская программа была разработана с учетом предыдущей редакции, предложений Министерства культуры Республики Беларусь и обобщенных исследований прошлых лет. Принимались во внимание республиканские, областные, городские перспективные планы реконструкции, сохранения и изучения памятников истории и культуры, развития культуры, сети музеев. Например, показательными стали достижения по итогам выполнения программы, запланированной на 2000-2005 гг. [2, c. 3-17].

В 2000 г. на территории Гродно было обнаружено и поставлено на учет 500 памятников. Среди них 90 памятников истории (56 из них республиканского значения), 10 памятников археологии, 32 памятника искусства. Наличие городской застройки высокой степени сохранности придавало исключительный статус и ценность для города, имевшего архитектурное и градостроительное наследие XII - XX вв., ансамбли и комплексы, застройку исторического центра, кварталов, площадей, улиц, остатки древней планировки, гражданскую, промышленную, культовую архитектуру. Гродно насчитывало 425 памятников архитектуры (153 объекта из них были включены под отдельными номерами в перечень памятников республиканского значения).

Основные направления городской программы «Наследие» сосредотачивались на сохранении, возрождении, развитии и приспособлении объектов архитектурного наследия под новые функции. В рамках реализации программы предусматривалось создание музеев, исследовательская работа по подготовке приложений к книге «Память», деятельность топонимической комиссии, реставрационные мероприятия. Основные цели этого раздела программы - охрана, изучение, систе- матизация, рациональное использование памятников, их реставрация и реконструкция для создания исторической и культурной среды города, ставилась задача разработки в соответствии с законодательством списка историко-культурных ценностей. Эти задачи должны были быть выполнены в 3-летний срок (2000-2003 гг.) Ответственность за выполнение возлагалась на отдел культуры горисполкома и управление культуры облисполкома.

На управление архитектуры и градостроительства, отдел культуры горисполкома возлагалась задача контроля соблюдения правил застройки исторического центра, подготовка проекта концепции размещения малых архитектурных форм в историческом центре города, а также эскиза застройки и технико-экономическое обоснование регенерации квартала исторической застройки в границах ул. Большая Троицкая - ул. Виленская река Городничанка - ул. Замковая (2000-2002 гг).

Проводились подготовительные работы по пилотному проекту ревитализации исторического центра Гродно в рамках сотрудничества Республики Беларусь и Совета Европы. Концепция проекта сосредоточивалась на реализации ряда мероприятий, а точнее работах по реставрации Коложской церкви XII в. Актуальными являлись технологические вопросы укрепления холма, противооползневые работы на берегу реки Неман.

Срок реализации планов был определен на 2000-2001 гг., ответственными за контроль были назначены Комитет по реставрации и консервации историко-культурных ценностей Министерства культуры, Дирекция по реставрации и консервации ценностей Гродненского облисполкома. Реставрационные мероприятия были начаты на здании Государственного музея истории религии (дворец Хрептовичей), памятнике архитектуры начала XIX в., ответственными за выполнение были назначены Управление культуры Гродненского облисполкома, Дирекция по реставрации и консервации; работы на здании библиотеки им. Е. Карского (исполнители те же), мост Старого замка XVIII ст.; мероприятия по благоустройству городских некрополей, а именно старого кладбища (XVIII - XX вв.), каплица XX в. на старом кладбище. Кураторство было возложено на ОО «Белорусское добровольное объединение охраны памятников истории и культуры».

Были запланированы мероприятия по реконструкции, реставрации, ремонту, благоустройству объектов: монумент в честь 850-летия Гродно (новый парк), военное кладбище по ул. Володар- 
ского, ул. Белуша, памятник-скульптура воина с венком, обелиск-скульптура (братская могила) воинов и партизан (парк Ж. Жилибера), бюсты Э. Ожешко и Я. Купале. Не остались без внимания памятники промышленной архитектуры водонапорные башни XIX - XX в. Срок исполнения мероприятия был намечен на 2000-2002 гг. Шефство за объектами было возложено на комбинат искусства Гродненской областной организации художников.

Благоустройство территорий общественного пользования было запланировано в парке им. Жилибера. Территория парка включала бывший садово-парковый комплекс «Городницы» конца XVIII в. Цикл работ выполнялся с участием и под руководством инспекции природных ресурсов и охраны окружающей среды Гродненского горисполкома, а также аграрного университета, парк «Румлево» (второй половины XVIII в.). Реализация городской программы предусматривала передачу в собственность православной епархии здания бывшего архиерейского подворья (XVIII в.). Проектные и ремонтно-восстановительные работы курировались облисполкомом и епархией. В центре города предусматривались дополнительные площади для объектов культуры [3, с. 213].

Гродненским городским исполкомом ещё в начале 1990-х гг. был актуализирован вопрос придания закрытым старым некрополям города статуса памятника истории и культуры в соответствии с законодательством и используемой терминологией того периода. Подтверждением намеченных планов стало принятие решения № 117 от 19.09.1990 г. Гродненского горисполкома «О придании статуса памятников истории и культуры католическим, православным и еврейским кладбищам». Горисполком просил облисполком присвоить кладбищам статус памятников истории и культуры местного значения и взять их под охрану [3, с. $213 ; 10$, с. 211].

Благоустройство городского пространства, а вместе с тем создание условий для охраны недвижимых историко-культурных ценностей, являлось частью реализации генерального плана города по созданию художественно-осмысленного, экономически-целесообразного и удобного для жизни горожан пространства. Генеральный план содержал концепцию художественной среды города, разработку модульных малых архитектурных форм, эстетизацию наружной уличной рекламы, благоустройство территорий общественного использования, например привокзальной площади. Гродненским горсоветом было принято решение № 263 от 28.10.1991 г. «О формировании художественного облика города». В связи с этим Управление по реставрации и консервации памятников истории и культуры провело обследование взятых под охрану зданий исторического центра, отдельных деталей архитектурных форм [4, с. 47-51].

Среди задач, которые реализовывались в рамках комплексной программы «Наследие», особое место уделялось вопросам увековечения памяти погибших в годы военных лихолетий. Среди направлений деятельности выделялись такие: 1) содействие общественным организациям в деле благоустройства мест захоронений; 2) мероприятия по перезахоронению; 3) распространение знаний о событиях и именах, связанных с годами войн.

В соответствии с этим направлением планомерно был совершен комплекс мероприятий, а именно решением исполкома Гродненского облсовета от 18.07.1994 г. № 240 «О регистрации Ассоциации по восстановлению мест захоронений военнослужащих, погибших во время мировых войн», был зарегистрирован Устав общественной организации «Примирение и Покой». В 1994 г. состоялась конференция, по итогам которой был принят устав ассоциации. Учредителями организации выступил Фонд социальной защиты бывших военнослужащих, Союз поляков Беларуси, Центр немецкой культуры.

Миссия организации основывалась на нескольких направлениях: поисково-исследовательская; восстановительная; гуманитарная. Силами ассоциации осуществлялось восстановление мест захоронений военнослужащих; проводились реставрационные работы на объектах военной инженерии; велась работа по поддержке дружественных отношений и налаживанию новых контактов в культурной и гуманитарной сфере. Например, был проведен ряд совместных фотовыставок с немецкой и польской стороной, а также конференции, проводимые международными организациями в борьбе за мир. В состав ассоциации был включен ряд общественных организаций: Гродненское отделение Белорусского демократического объединения ветеранов войны и труда, представители вооруженных сил и правоохранительных органов, областной военкомат, совет ветеранов участников первых боев на Гродненщине [8, с. 102].

На протяжении десятилетия с 1991 по 2000 гг. проводились реставрационные работы по таким объектам, как замок в деревне Крево, замок в деревне Гольшаны, мечеть в деревне Довбутишки, усадьба Огинского в деревне Залесье; 
регенерация исторического центра города Новогрудок, реставрация дворцово-паркового комплекса в деревне Щорсы, старый замок в городе Лида, замок в деревне Гайтюнишки. В 2001 г. был актуализирован вопрос регенерации и вовлечения в культурную, туристско-экскурсионную сферу Мирского замка - историко-культурной ценности, включенной в 2000 г. в список ЮНЕСКО. В соответствии с постановлением Совета Министров Республики Беларусь от 23.07.2001 г. «О первоочередных мерах по сохранению и возрождению исторических центров городов Беларуси» администрацией Кореличского района и Гродненского облисполкома в преддверии республиканского праздника - Дня белорусской письменности - было подготовлено прошение в Министерство культуры о выделении средств на восстановление замка и парка в поселке Мир.

Реставрационная деятельность в отношении Мирского замка на протяжении нескольких десятилетий осуществлялась медленно. Статус Мирского замка как историко-культурной ценности национального значения был подтвержден постановлением Белорусского республиканского научно-методического совета по вопросам историко-культурного наследия от 04.06.1999 г. Процесс ускорила комиссия Палаты представителей Национального собрания Республики Беларусь по образованию, культуре, науке и научно-техническому прогрессу, утвердив постановление по этому объекту. В 2001 г. Министерством культуры был разработан проект создания на базе замкового комплекса международного культурно-образовательного центра под эгидой ЮНЕСКО. Документ предусматривал размещение гостиницы, конференц-зала, музейных экспозиций, центра подготовки специалистов в области культурного туризма [12, с. 303-306].

Выводы. Практика работы Гродненского областного исполнительного комитета опреде- лила организационно-управленческие подходы (с учетом региональной специфики) к реализации государственной политики Беларуси в области сохранения недвижимого историко-культурного наследия в 1990-е - начале 2000-х гг. Гродненский облисполком сумел привнести свой инновационный подход в управление недвижимыми историко-культурными ценностями.

Показательно, что в начале $1990-$ х гг. в условиях недостатка республиканских капитальных вложений местными исполнительно-распорядительными органами были применены эффективные административные и экономические меры за счет создания производственно-коммерческого управления, которое курировало широкий спектр мероприятий по регенерации объектов и включения их в сферу хозяйствования, туристско-экскурсионную деятельность. Материальные недвижимые историко-культурные ценности уже тогда рассматривались как хозяйственные единицы.

Принципы управления объектами позволили достичь высоких показателей в продуктивности реставрации, ремонта, благоустройства, содержания и приспособления материальных недвижимых историко-культурных ценностей под новые социокультурные функции. Гродненский облисполком разработал свою собственную схему управления местным хозяйством и коммунальной собственностью с особым вниманием к проблемам улучшения состояния историкокультурных ценностей.

Организационно-управленческие подходы к налаживанию работы структурных подразделений Гродненского облисполкома, то есть распределение полномочий между структурными подразделениями в реализации государственной политике, имели свои особенности. Программные документы, принятые еще в начале 1990-х гг., надолго определили вектор восстановления историко-культурных объектов Гродненской области.

Список литературы:

1. Государственный архив Гродненской области (далее - ГАГО). Ф. 482. Оп. 2. Д. 235.

2. ГАГО. Ф. 471. ОП. 2. Д. 519.

3. ГАГО. Ф. 482. ОП. 2. Д. 681.

4. ГАГО. Ф. 484. ОП. 2. Д. 817.

5. ГАГО. Ф. 675. ОП. 2. Д. 2.

6. ГАГО. Ф. 675. Оп. 2. Д. 8.

7. ГАГО. Ф. 1003. ОП. 2. Д. 213.

8. ГАГО. Ф. 1071. ОП. 5. Д. 3200.

9. ГАГО. Ф. 1266. ОП. 3. Д. 4754.

10. Гродненская область в документах и материалах (1944-1995 гг.) / сост. Л.И. Юнина [и др.]. Слоним : Слонимская типография, 2004. 432 с.

11. Мартыненко И.Э. Правовая охрана историко-культурного наследия. Гродно : ГРГУ, 2005. 251 с. 
12. Национальный архив Республики Беларусь (НАРБ). Ф. 7. Оп. 16. Д. 4759.

13. Саяпин В.Ю. Гродненские памятники и скульптуры. Гродно : ЮрСаПринт, 2014. 106 с.

14. Саяпин В.Ю. История Гродненских площадей. Гродно : ЮрСаПринт, 2011. 108 с.

15. Саяпин В.Ю. Пешком по Ожешко и Советской. Гродно : ЮрСаПринт, 2011. 102 с.

16. Ганський В.О. Організаційно-економічне забезпечення процесів публічного управління історикокультурною спадщиною для забезпечення ії сталого розвитку. Актуальні питання публічного управління та адміністрування в контексті реалізаиї̈ адміністративної реформи : матеріали Всеукр. науково-практ. конф., 19 червня 2018 р. Умань : УНУС, 2018. С. 189-191.

17. Ганський В.О. Публічне управління ресурсами спадщини в системі участі територіальної громади. Становлення механізму публічного управління розвитком сільських територій як пріоритет державної політики децентралізації : матеріали Міжнар. науково-практ. конф., 4 грудня 2018 р. Житомир : ЖНАУ, 2018. С. 56-59.

18. Гродназнаўства. Гісторыя еўрапейскага горада / А. Госцеў, А. Дабрыян. В. Карнялюк (i інш.). Вроцлаў : KEW, 2012. 340 c.

\section{Andreichyk K.V. PROTECTION OF IMMOVABLE HISTORICAL AND CULTURAL PROPERTY IN THE REGIONS OF BELARUS IN 1990S AND EARLY 2000S (ON EXAMPLE OF GRODNO REGION)}

The article deals with the activities of local executive authorities of the basic and urban territorial level of the Republic of Belarus for the protection of immovable historical and cultural values. On the basis of archival sources State archive of the Grodno region is considered the structural units of the Grodno Regional Executive Committee in 1991-2005 for the protection, preservation, restoration and adaptation to new socio-cultural functions of immovable material historical and cultural values of the rich historical-cultural values of Grodno region and Grodno city in complex socio-economic and socio-political period of the late of 20th century.

Special attention is paid to the activities of the Main Department of Architecture and Urban Planning of the Grodno Regional Executive Committee, the Department for the Restoration and Conservation of Historical and Cultural Monuments, the State Production and Commercial Department for the Restoration of Historical and Cultural monuments, etc. Among other things is analyzed the first regional comprehensive program of research, preservation and promotion of cultural heritage "Heritage".

The study examines features of the mechanism of management of regional fund of immovable historical and cultural values, including the implementation including targeted regional and municipal programs for the protection, preservation, restoration and use of monuments of history and architecture within the Grodno region and Grodno city, a range of security measures on an accomplishment of territories of security zones of settlements of the region, restoration and conservation of immovable objects of historical and cultural heritage (castles, palaces, mansions, temples, etc.), reconstruction of the historical development of settlements in the region and its improvement, memorialization of memorable places associated with the events of the First and Second world wars, etc.

Key words: cultural heritage, historical and cultural values, protection of heritage monuments, local government and self-government bodies, Belarus, Grodno region. 